\title{
DIGITAL MARKETING STRATEGY OF SMALL AND MEDIUM ENTERPRISES FOR SNACK IN BOGOR CITY
}

\author{
Aulia Ratnadianti Suharjo*)1, Idqan Fahmi*), and Sufrin Hannan**) \\ *) School of Business, IPB University \\ Jl Raya Pajajaran Kampus IPB Baranangsiang, Bogor 16129, Indonesia \\ **) Graduate School, Pakuan University \\ Jl. Pakuan PO Box 452 Bogor 16143, Indonesia
}

\begin{abstract}
Snack MSME (Micro, Small \& Medium Enterprises) is one of the business unit categories that has great potential to be developed at this moment. This study aimed to formulate digital marketing alternative strategies for snack MSME in Bogor. This study began with the analysis of respondent characteristics, both for MSME respondents and consumer respondents. The next step was an analysis of marketing strategies of snack MSME and consumer online purchasing behavior pattern This study also analyzed consumer satisfaction level to MSME digital marketing performance with Importance Performance Analysis, while also mapping consumer preferences based on digital marketing mix. The final step was to develop a digital marketing strategy based on the $4 \mathrm{C}$ marketing mix. This research resulted in eleven digital marketing strategies, which were increasing the durability of snack food products, providing a variety of diverse product flavors, designing attractive packaging and brand appearance, providing information on products nutritional value, determining affordable prices, utilizing appropriate information media, choosing appropriate promotional media, creating attractive promotions for consumers, displaying consumer testimonials, displaying honest pictures and product descriptions, and providing various types of the payment instrument.
\end{abstract}

Keywords: consumer online snack purchasing behavior, marketing mix $4 \mathrm{C}$, snack MSME, digital marketing strategy

\begin{abstract}
Abstrak: UMKM makanan ringan menjadi salah satu unit usaha yang memiliki potensi yang besar untuk terus dikembangkan saat ini. Penelitian ini bertujuan untuk merumuskan alternatif strategi pemasaran digital untuk UMKM makanan ringan di Kota Bogor. Penelitian ini diawali dengan menganalisis strategi pemasaran UMKM makanan ringan saat ini dan pola perilaku pengambilan keputusan konsumen. Penelitian ini juga menganalisis tingkat kepuasan konsumen terhadap kinerja pemasaran digital makanan ringan melalui metode Importance Performance Analysis. Tahap terakhir yaitu menyusun alternatif strategi pemasaran digital berdasarkan bauran pemasaran 4C. Penelitian ini menghasilkan sebelas rekomendasi strategi pemasaran digital, yaitu peningkatan daya tahan produk makanan ringan, menyediakan variasi rasa produk yang beragam, mendesain tampilan kemasan dan merek yang menarik, mencantumkan informasi nilai gizi produk, menetapkan harga yang terjangkau, menggunakan media informasi yang tepat, memilih media promosi yang tepat, memberikan promosi yang menarik bagi konsumen, menampilkan testimonial konsumen, menampilkan gambar dan deskripsi produk yang jujur, dan menyediakan berbagai jenis alat pembayaran.
\end{abstract}

Kata kunci: bauran pemasaran 4C, UMKM makanan ringan, perilaku pembelian makanan ringan online, strategi pemasaran digital

\footnotetext{
${ }^{1}$ Corresponding author:

Email: dianauliaratna@gmail.com
} 


\section{INTRODUCTION}

Economic growth in Indonesia is supported by diverse sectors, one of them is MSME (Micro, Small and Medium Enterprises). MSME plays a vital role in national economic development, shown by its contribution to $60 \%$ GDP of Indonesia in 2017. MSME is the biggest business actor, consisted of $99.9 \%$ of businesses in Indonesia. Badan Pusat Statistik (Central Bureau of Statistics) data showed in 62.922.617 business units in Indonesia were MSME (BPS, 2017). Bogor is one of the cities with the highest MSME development growth. Based on a survey by Dinas Koperasi dan UMKM Kota Bogor, it is known that MSME in Bogor contributes to $67 \%$ of Bogor GDP, which also affects Bogor economic growth by $6.6 \%$.

The considerable potential of MSME to support Indonesia's economic growth cannot be separated with its problems, both internal (lack of capital and technological awareness) and external (business permision, raw material, marketing and integration to regional and global supply chain) (Gunartin, 2017). This issue is also supported by a study from Maulida dan Yunani (2018), that showed the greatest problems Indonesia MSME had were capital (51.09\%) and marketing (34.72\%).

Technological development in the internet era pushes changes to many daily aspects, one of them is the change to consumer behavior of Indonesian people which prefer to more instant and practical things, which in turn escalate online shopping model. We Are Social data showed that the percentage of Indonesian people who bought products and services online reached $41 \%$ in 2017, growing 15\% from previous year (Kama, 2018).

Srinivisan et al. (2016) study showed that technological use in MSME has many advantages. First, business owners can get live feedback, Second, social media gives real-time market trends and opportunities. Third, business owners can monitor their product, whether it is already suitable for consumer preference or not, and they can also explore consumer's most desired products. Mokhtar et al. (2017) and study showed that technological use in MSME can also improve market size, reduce marketing costs, improve sales, and forge a greater relationships with consumer.
Technological use in MSME enables business owners to acquire detailed information about consumer behavior, consumer preference, consumer needs, and consumer spending pattern. Those information are crucial for determining prices, promotion, and product development (Bhayani dan Vachhani, 2014).

Digital media use in the marketing of food products is proved to be more effective to boost MSME profit than conventional marketing one (Lisawati, 2016; Khairani et al. 2018). Setiawan et al. (2018) and Srirejeki, (2016) study showed that digital marketing can boost food MSME profit by $10 \%-32 \%$.

The substantial opportunities to market their products online have not been taken by MSME. It is showed by Kominfo data from 59 million MSME in Indonesia, only $7.7 \%$ already use internet for marketing (Kominfo 2018).

One of food MSME categories in Bogor is snack MSME. Several studies showed that snack product is one of the most product bought online at this moment. Snack consumption growth per capita is also increasing every year until 2018 (Figure 1).

The sizeable potency of snack business gives snack MSME in Bogor a way to compete in local market by using various media as a marketing platform, and one of them is digital media. In addition, this situation can be seen as a chance for Bogor to continually develop food and drink industries, so they can give more contribution to Bogor economic development.

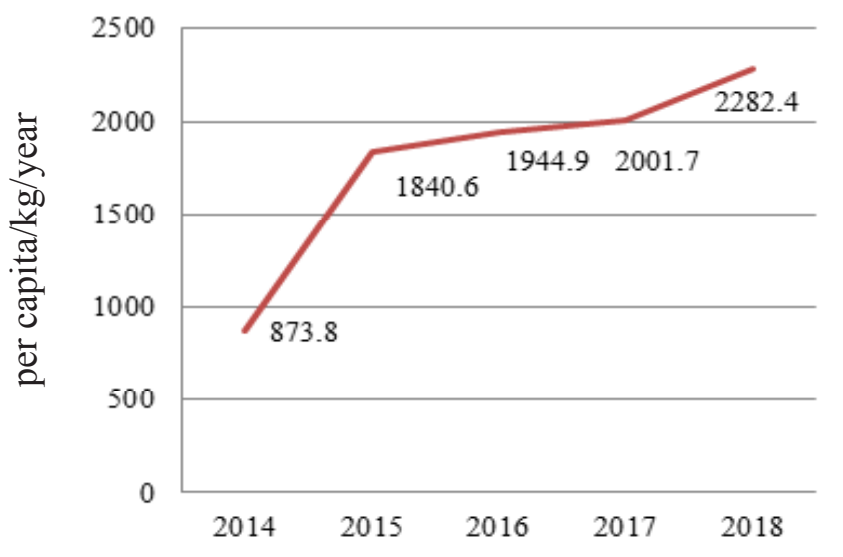

Figure 1. Snack consumption growth in Indonesia (Ministry of Agriculture, 2018) 
Another challenge faced by snack MSME was that every consumer in Bogor City certainly had different needs and wants of snacks. They also had different choices of media used to search snack information. That situation was important for snack MSME in Bogor City to consider consumer preferences on their marketing strategy.

Previous study only analyzed internal and external factors of MSME to formulate marketing strategy. This study on Digital Marketing Strategies for Snack MSME in Bogor is aimed to formulate alternative digital marketing strategies for snack MSME based on two points of view, which are producers and consumers.

\section{METHODS}

This study was conducted in Bogor, which was chosen purposively based on the fact that snack MSME growth in Bogor was increasing every year. This study was carried out from September 2019 to February 2020. This study used two data sources, which were primary data obtained by direct observation, questionnaire fill-in, and in-depth interview with respondents, and secondary data in form of literature studies to support snack MSME characteristics in Bogor. The latter data were obtained from Bogor Cooperative and MSMEs Office and the City of Bogor Industry and Trade Office. The type of data were qualitative and quantitative.

MSME business owners were selected as respondents by purposive sampling technique with criteria, which were: Business owner who owns and manages directly snack MSME; The snack MSME which is registered in the Bogor Cooperative and MSMEs Office and the City of Bogor Industry and Trade Office; Snack MSME employs mixed marketing strategy; MSME that produces snacks; Be willing to give information.

The number of respondents obtained were 22 MSME, which employs a mixed marketing strategy. Snack MSME in this study was assumed to be representative of snack MSME condition in Bogor, as it still undergoes a transition process from conventional to digital marketing, so there is no MSME which employs solely digital marketing.
As for consumer respondents, they were selected by convenience sampling technique with criteria such as: Is 14-35 years old; Live in Bogor; Have bought snack online for at least three times in a year; Be willing to give information. A total of 100 consumers were selected in this study.

Alternative marketing strategy in this study was formulated by two points of view, which were producers and consumers. This study began with analysis of respondent characteristics, both for MSME respondents and consumer respondents. The next stage was analysis of marketing strategies of snack MSME and consumer online purchasing behavior pattern This study also analyzed consumer satisfaction level to MSME digital marketing performance with Importance Performance Analysis, while also mapping consumer preferences based on digital marketing mix. The final stage was to develop a digital marketing strategy based on the 4C marketing mix (Figure 2).

Data analysis methods in this study were thurstone analysis, correspondence analysis, and ImportancePerformance analysis. Thurstone analysis was used to rank attribute importance. This ranking was necessary to give insight into what consumer needs.

Correspondence analysis was used to analyze paired factors of consumer respondent characteristics, such as sex, age, and monthly income, with snack online purchase decision-making behavior. Importance Performance Analysis is a technique to measure importance and performance of various attributes that can boost the development of effective marketing activities. Performance level displays consumer perception of product quality and services provided by seller. Meanwhile, importance level exhibits the importance of such service for consumer (Yildiz, 2011).

\section{RESULTS}

\section{Respondent Characteristic}

This study had two types of respondent, which were consumer respondents and snack MSME respondents. Consumer respondents have mainly consisted of people who were 23-26 years old with undergraduate or higher education. The main occupation was company staff with average monthly income less than 5 million rupiahs 
and average snack monthly spending between 50-100 thousand rupiahs (Table 1). Snack MSME respondents were dominated by woman aged 51-60 years old with bachelor's degree education. Most of MSME were founded between 2015 and 2019 with average capital Rp500,000 - Rp1,500,000 (Tabel 2).

\section{Marketing Strategy of Snack MSMEs in City of Bogor}

\section{Product Strategy}

There was a various type of snacks sold by snack MSMEs in City of Bogor, such as chips, crackers, and pastries. The snack product was inseparable from the type of snack packaging. Plastic was the most type of packaging used by snack MSMEs with an average content size of 50-100 grams.

\section{Pricing Strategy}

The price of snacks produced by snack MSMEs in Bogor City was diverse for 100 grams package. The most offered price was in the range of Rp10,000 Rp20,000. Product pricing was based on production costs, competitor prices, and consumer capabilities. Kusumawaty (2018) said pricing strategies could be determined based on competitor prices.

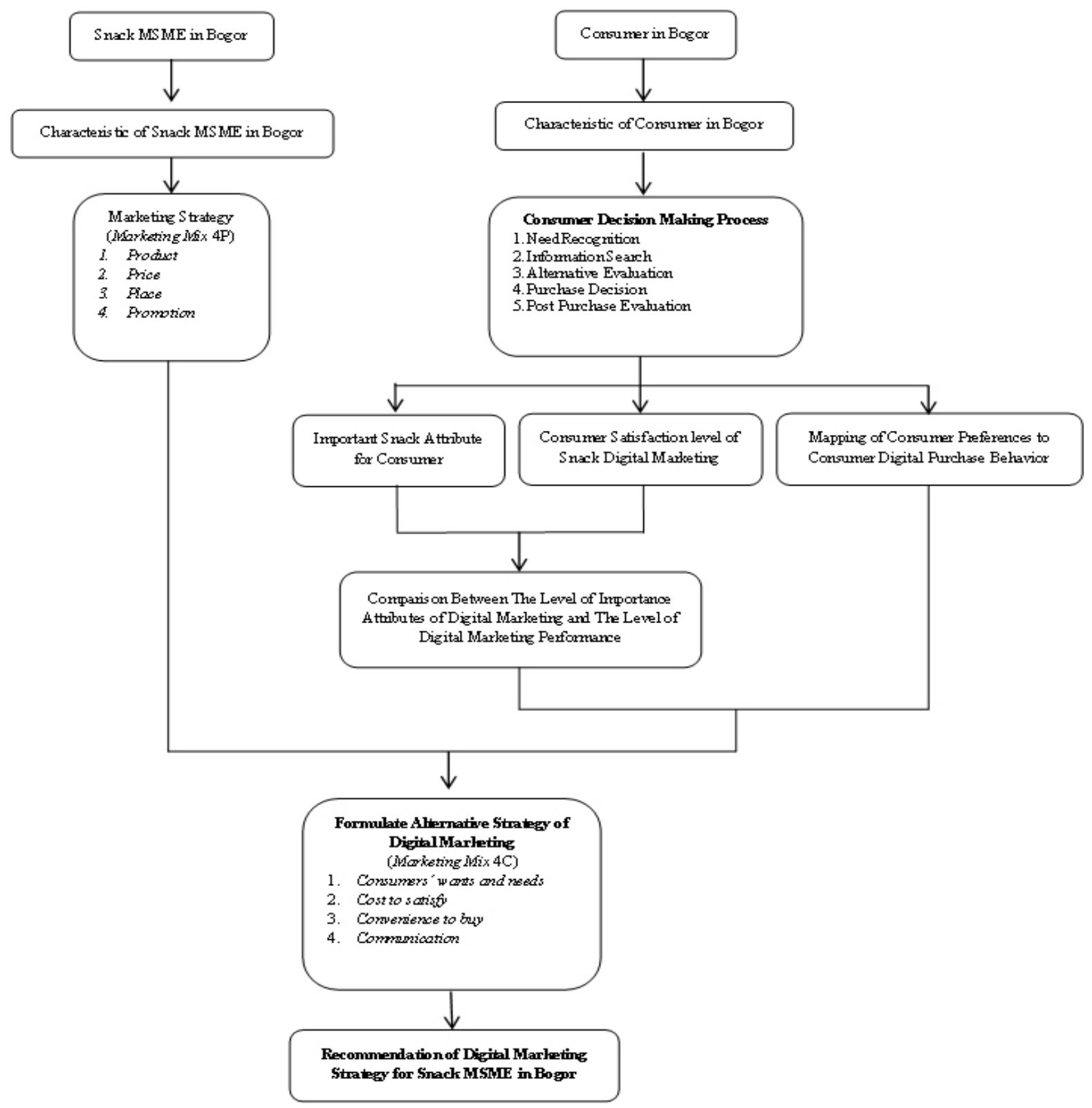

Figure 2. Research framework 
Table 1. Consumer respondent characteristic

\begin{tabular}{|c|c|c|}
\hline \multirow[b]{2}{*}{ Respondent Characteristic } & \multicolumn{2}{|c|}{ Total $(n=100)$} \\
\hline & $\begin{array}{c}\text { Total } \\
\text { (person) }\end{array}$ & $\begin{array}{c}\text { Percentage } \\
(\%)\end{array}$ \\
\hline \multicolumn{3}{|l|}{ Age } \\
\hline $19-22$ year old & 15 & 15 \\
\hline $23-26$ year old & 69 & 69 \\
\hline $27-30$ year old & 10 & 10 \\
\hline $31-35$ year old & 6 & 6 \\
\hline \multicolumn{3}{|l|}{ Gender } \\
\hline Male & 19 & 19 \\
\hline Female & 81 & 81 \\
\hline \multicolumn{3}{|l|}{ Education } \\
\hline High School & 4 & 4 \\
\hline $\mathrm{S} 1 / \mathrm{S} 2 / \mathrm{S} 3$ & 86 & 86 \\
\hline Academy/Diploma & 10 & 10 \\
\hline \multicolumn{3}{|l|}{ Occupation } \\
\hline Student & 25 & 25 \\
\hline PNS/Police/TNI & 7 & 7 \\
\hline Hononary Staff & 9 & 9 \\
\hline General Employee & 37 & 37 \\
\hline BUMN Employee & 2 & 2 \\
\hline Entrepreneur & 12 & 12 \\
\hline Housewife & 7 & 7 \\
\hline Health Worker & 1 & 1 \\
\hline \multicolumn{3}{|l|}{ Marital Status } \\
\hline Not Married & 77 & 77 \\
\hline Married & 23 & 23 \\
\hline \multicolumn{3}{|l|}{ Average Monthly Income } \\
\hline$<\mathrm{Rp} 5,000000$ & 67 & 67 \\
\hline $\mathrm{Rp5}, 000,000-\mathrm{Rp} 10,000,000$ & 27 & 27 \\
\hline Rp10,000,000 - Rp15,000,000 & 3 & 3 \\
\hline Rp15,000,000 - Rp20,000,000 & 1 & 1 \\
\hline$>\operatorname{Rp} 20,000,000$ & 2 & 2 \\
\hline \multicolumn{3}{|c|}{ Average Monthly Expenditure of Snack } \\
\hline$<\operatorname{Rp} 50,000$ & 13 & 13 \\
\hline Rp50,000 - Rp100,000 & 26 & 26 \\
\hline Rp100,000 - Rp150,000 & 23 & 23 \\
\hline Rp150,000 - Rp200,000 & 12 & 12 \\
\hline$>\operatorname{Rp} 200,000$ & 26 & 26 \\
\hline
\end{tabular}

\section{Promotion Strategy}

Snacks produced by MSMEs in Bogor were marketed by using various types of digital media. Marketplace was one of the most used media (30.5\%) by MSMEs in Bogor. The ease of features provided by the marketplace in marketing product was the main reason to market the snack by MSMEs in Bogor. Priambada (2017) said that
Table 2. Snack MSME respondent characteristics

\begin{tabular}{|c|c|c|}
\hline \multirow[b]{2}{*}{ Respondent Characteristic } & \multicolumn{2}{|c|}{ Total $(n=22)$} \\
\hline & $\begin{array}{c}\text { Total } \\
\text { (people) }\end{array}$ & $\begin{array}{l}\text { Percentage } \\
(\%)\end{array}$ \\
\hline \multicolumn{3}{|l|}{ Age } \\
\hline $21-30$ year old & 6 & 27.3 \\
\hline $31-40$ year old & 5 & 22.7 \\
\hline $41-50$ year old & 4 & 18.2 \\
\hline $51-60$ year old & 7 & 31.8 \\
\hline \multicolumn{3}{|l|}{ Gender } \\
\hline Male & 5 & 22.7 \\
\hline Female & 17 & 77.3 \\
\hline \multicolumn{3}{|l|}{ Education } \\
\hline Junior High School & 1 & 4.5 \\
\hline Senior High School & 7 & 31.8 \\
\hline Academy/Diploma & 4 & 18.2 \\
\hline Bachelor (S1) & 10 & 45.5 \\
\hline \multicolumn{3}{|l|}{ Year of Establishment } \\
\hline $2011-2014$ & 4 & 18.2 \\
\hline $2015-2019$ & 18 & 81.8 \\
\hline $\begin{array}{l}\text { Number of Permanent } \\
\text { Worker }\end{array}$ & & \\
\hline$<5$ people & 15 & 68.2 \\
\hline 5-10 people & 2 & 9.1 \\
\hline 15-20 people & 1 & 4.5 \\
\hline N/A & 4 & 18.2 \\
\hline \multicolumn{3}{|l|}{ Number of Contract Worker } \\
\hline$<5$ people & 8 & 36.4 \\
\hline N/A & 14 & 63.6 \\
\hline \multicolumn{3}{|l|}{ Initial Venture Capital } \\
\hline$<\operatorname{Rp} 500,000$ & 4 & 18.2 \\
\hline $\mathrm{Rp} 500,000$ - Rp1,000,000 & 9 & 40.9 \\
\hline Rp1,000,000 - Rp5,000,000 & 4 & 18.2 \\
\hline$>$ Rp5,000,000 & 5 & 22.7 \\
\hline
\end{tabular}

\section{Education}

Junior High School

Academy/Diploma

45.5

\section{Year of Establishment}

$2011-2014$

8.2

5

18.2

Number of Contract Worker

$<5$ people

6.4

\section{Initial Venture Capital}

one of the most media digital that used by MSME was website/blog (39\%).Higher consumer interest in digital marketing compared to conventional marketing was supported by Lodhi and Shoaib (2017) research which showed the fact that consumers were more interested in seeing online marketing than advertising on TV at this time. 


\section{Place Strategy}

Snack MSMEs had different distribution channel choices. Marketing by collaborating with reseller was desirable by MSMEs in City of Bogor besides marketing products through digital media. The distribution process of snack through reseller was approved by the snack MSMEs in Bogor who can seek market approval for their products without spending more. In addition, reseller can also help consumers to get snacks more easily. As the result, distribution channel was considered effective.

\section{Consumer Decision Making Process in Purchase of Snack Online}

\section{Introduction of Needs}

This process was certainly based on consumer motivation to bought snack online. The analysis showed that as many as $34.3 \%$ of consumers in Bogor were more interested to buy snack online because there were interesting promotions offered by seller. In addition, $32.1 \%$ of consumers decided to buy snack online because the products they need were not sold offline. The ease of payment process also encouraged $31.3 \%$ of consumers to buy snacks online.

\section{Information Search}

The most sought information source looked by $77 \%$ consumers were advertisements on social media. The information media used by snack MSMEs plays an important role to appeal to consumers to buy their products. Short duration videos had a big impact on $56 \%$ of consumers who bought snacks online. Other media was endorsements by celebrities/influencers (41\%). Endorse activity carried out by influencers/ celebrities creates a new marketing system that was quite effective for consumers.

\section{Alternative Evaluation}

Each consumer certainly had a different rating regarding attributes of existing snacks. Various snack attributes that were of primary importance to consumers are presented in Table 3. Thurstone analysis result showed that product taste was the most important attribute considered by consumer who buy snack online (26.1). The other important attributes for consumers were halal certification, product prices, BPOM/PIRT certification, and product content size with the value respectively $19.7 ; 15.9 ; 10.3 ; 7.5$. This result was in line with Dewi's study (2017) which showed that there were several attributes expected by consumers of snacks such as, marketing products that could reach many regions, ease of online purchasing, packaging that was able to maintain product quality, and products that were equipped with halal assurance aspects.

Table 3. Importance snack attribute for consumers

\begin{tabular}{clc}
\hline Ranking & Attributes & Score \\
\hline 1 & Product Taste & 26.1 \\
2 & Halal Certification & 19.7 \\
3 & Product Price & 15.9 \\
4 & BPOM.PIRT Certification & 10.3 \\
5 & Product Content Size & 7.5 \\
6 & Delivery Cost & 6.6 \\
7 & Consumer Testimonials & 5.7 \\
8 & Nutrition Content & 4.9 \\
9 & Various Taste of Product & 4.0 \\
10 & Suitable Description with Product & 4.9 \\
\hline
\end{tabular}

Purchase Decision

Consumer could buy snack online through various types of digital media. The types of media often used by consumers to buy snack were Marketplace (Tokopedia, Shopee, Lazada, etc) and Instagram by respectively $58 \%$ and $39 \%$. Most consumers had snack preference with 250 gram package size. The choice of content size was inseparable from the type of packaging material that snack used. Consumers preferred to choose snack packaged by plastic (42\%) at price range of Rp 10000 to $\operatorname{Rp} 20000$ per grams.

\section{Post-Purchase Evaluation}

Consumer evaluations end when consumers compare the perceived performance of online snack products and services to the expected performance. The analysis of customer satisfaction level showed that $97 \%$ of consumers were satisfied when buying snacks online and were willing to buy snacks online again. 


\section{Consumer Satisfaction Level of Snack Digital Marketing Performance}

Consumer satisfaction to snack products and service was analyzed with Importance Performance Analysis (IPA), which compares between consumer expectations level to snack producer performance (Figure 3). The product attributes evaluated in this analysis were nutritional content of the product, the perceived benefits of the product, product taste, halal certification, product durability, BPOM / PIRT certification, product price, shipping cost, size of product contents, variations in product taste, product packaging, and product brands. The service attributes evaluated were the suitability of the seller's description of the product, consumer testimonials, the suitability of the image with product, promotions provided by the seller, service speed, ease to acquire product, ease of payment, and product promotion media. The results of IPA matrix analysis for snack product and service attributes can be seen in Figure 3.
Importance Performance Analysis showed that product durability was the most prioritized product attribute to improve by snack MSMEs in Bogor. The shipping process faced a challenge to maintain the texture and form of snack products. Consumers assumed that the characteristic of snacks needed to be considered during the shipping process.

\section{Mapping of Consumer Preferences to Consumer Digital Purchase Decision Behaviour}

Consumer preferences mapping in this study were done with correspondence analysis that examined the relationship between consumer respondents demographic variables (age, gender, education, and income per month) with marketing mix variables (content size, type of packaging, product prices, type of information media, forms of promotion and type of promotional media).

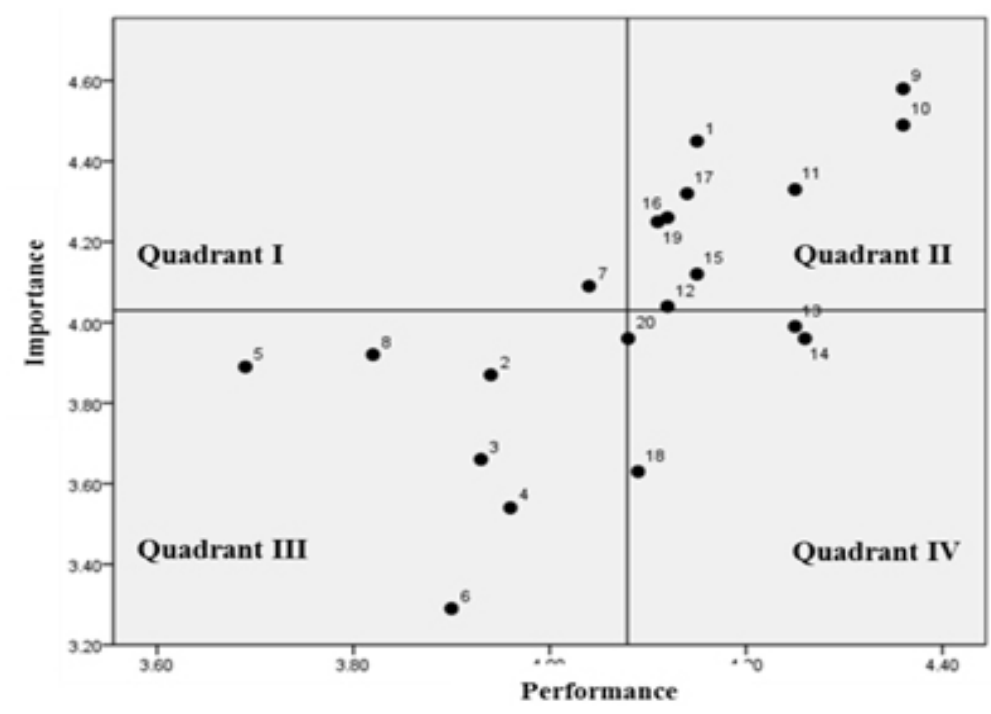

Information :

Quadrant 1 (Concentrate Here)

7 : Product durability

Quadrant II (Keep Up The Good Work)

1 : Product taste

9 : Halal certification

10 : BPOM/PIRT certification

11 : Product price

12 : Delivery cost

15 : Service speed

16 : Suitability of the image with the product

17 : Suitability of the seller's description of the product

19 : Consumer testimonials
Quadrant III (Low Priority)

2 : Product content size

3 : Various of product taste

4 : Product package apperance

5 : Product nutrition content

6 : Product brands

8 :Perceived benefits of the product

Quadrant IV (Possible Overkill)

13 : Ease of obtaining the product

14 : Ease of payment

18 : Product promotion media

20 : Promotion provided by the seller

Figure 3. Importance performance analysis snack online matrix 
Each age group of consumer respondents had a different choices to type of information media (Figure 4). Group of 19-22 yo and 23-26 yo preferred using information media such as marketplace, Instagram, and Whatsapp for searching snack information. This was a different choices from respondent group 27-30 yo who used two types of information media, which were marketplace and Instagram to find snack information. Meanwhile, respondent group 31-35 yo used marketplace, Instagram, and Facebook to find snack information.

The application Whatsapp was considered as media that makes it easy for respondent group of 19-26 yo to find detailed snack information from seller. Information obtained through that media could be more trusted by respondents aged 19-26 yo because they also interact directly with sellers before deciding to purchase snack.

Different things were shown by respondent group 3135 yo who favored Facebook media compared to other types of media. Facebook was considered to have more features easier to use to find snacks information. In addition Facebook was also considered to be able to provide a lot of information compared to other types of media.

Differences in information media types chose by gender group respondent can be seen in Figure 5. Male groups preferred Instagram to find snacks information, while female groups preferred marketplace as their information media. In addition, female gender groups also used Facebook to search for snack information.

Differences media information preferences between male and female were thought to be caused by features of that media. Marketplace was a type of digital media that provides various types of snack products from various sellers accompanied by sufficiently detailed information for each product, so it was preferred by women groups. While Instagram is a type of digital media that offers products more personally by sellers, so that it can lead to higher trust between sellers and buyers.

The respondent gender groups of male and female also had differences of promotional media choice when buying snacks online (Figure 6). Both gender groups were more interested in seeing snack promotions in the form of short videos. But in the female gender group, endorsement via celebrities or influencers was the most preferred promotional media. Female gender groups had more attention to social media development related to celebrities and influencers, thus encouraging this group to be more sensitive to various types of endorse conducted by celebrities and influencers to find product information. Each respondent had different preference of snack products content size based on income groups, which can be seen in Figure 7.

The analysis showed that the income group in the range of $<$ Rp. 5000000 per month preferred snacks that have 250 gram contents size, while the income group $>\mathrm{Rp}$. 15000000 per month preferred larger content size snack products at 500 grams. The analysis showed that the higher-income per month had the greater snacks contents size purchased. The analysis also showed that lower-income of consumer respondents had more varied contents size, starting from 50 grams, 100 grams, 250 grams, to 500 grams. Different content size preferences in the income groups also occurred in product price preferences (Figure 8).

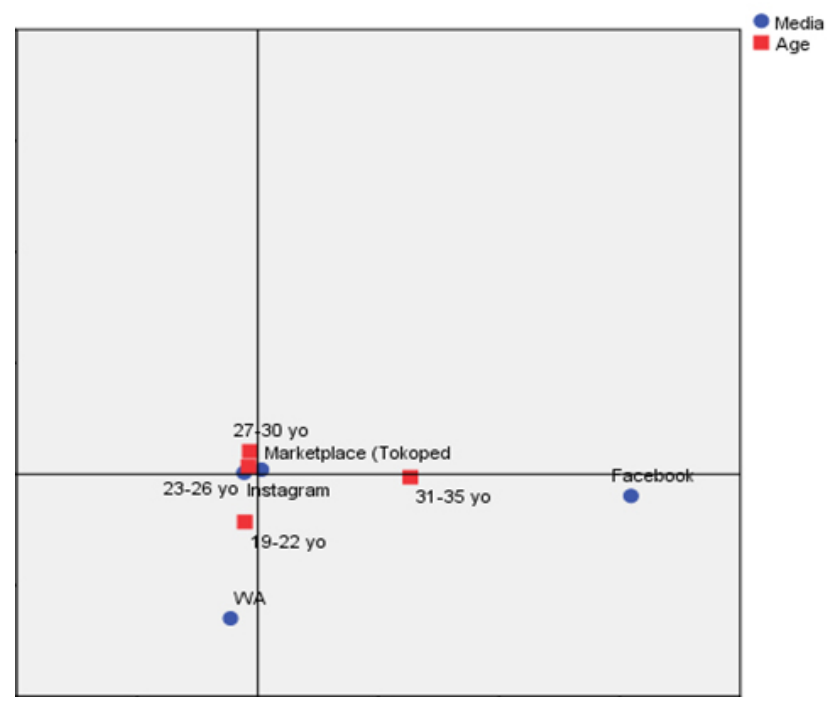

Figure 4. Information media preferences based on age respondent

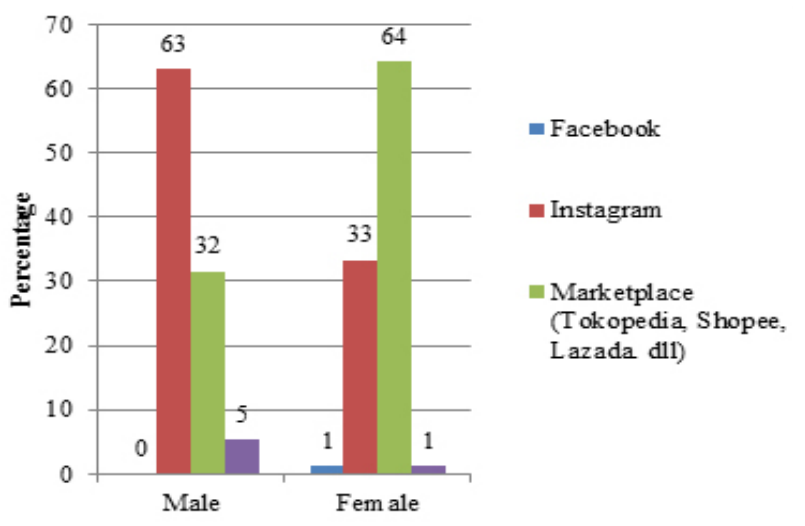

Figure 5. Information media preferences based on gender respondent 


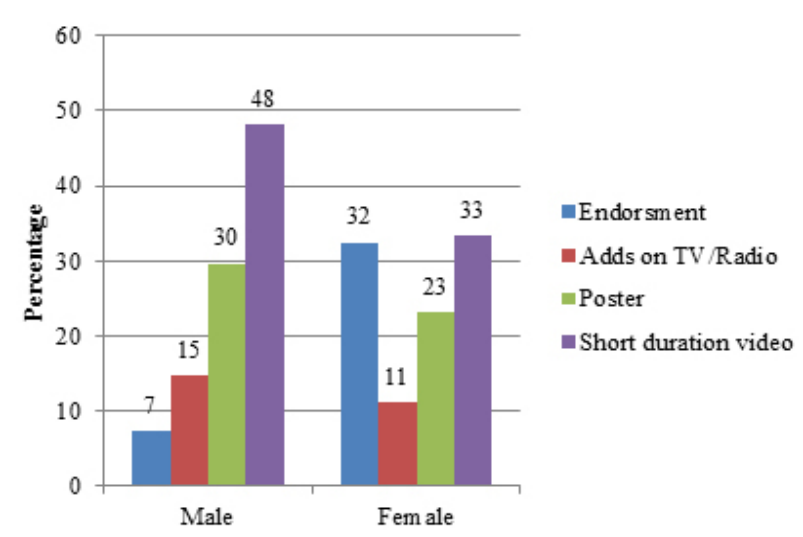

Figure 6. Promotion media preferences based on gender respondent

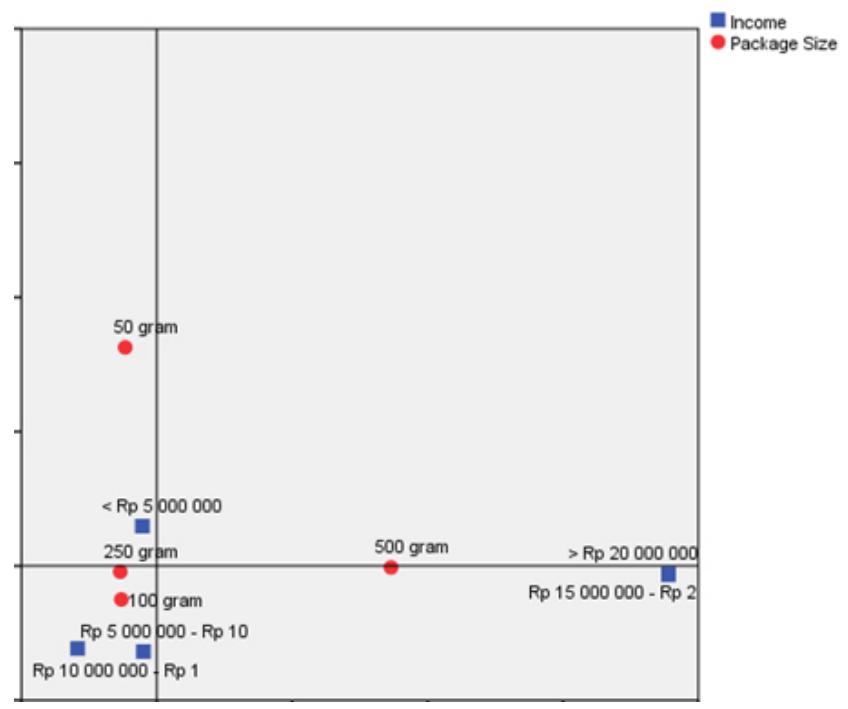

Figure 7. Content size preferences based on income group respondent

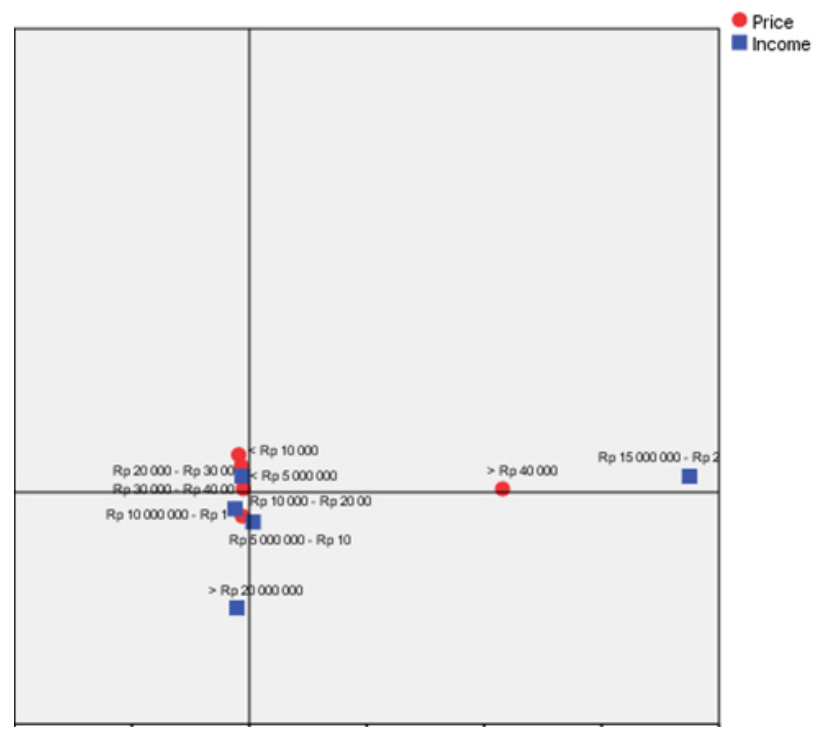

Figure 8. Product price preferences based on income group respondent
The analysis showed that the respondent who had income in the range of $<\mathrm{Rp} 5,000,000-\mathrm{Rp} 10,000$ 000 had variety of product price preferences, ranging from $<\mathrm{Rp} 10,000$; Rp10,000 - Rp20 000; Rp20,000 Rp30,000; Rp30,000 - Rp 40 000; and >Rp 40,000. This was different from the income group in the range of Rp10,000,000 - Rp15,000,000 which only had two types of product price preferences, which were Rp10,000 - Rp20,000 and Rp20,000 - Rp30,000. The income group Rp15,000,000 - Rp20,000,000 and

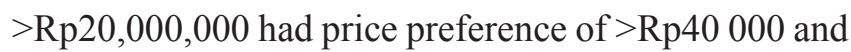
Rp10,000 - Rp20,000.

The results indicated that the respondents who had higher monthly income do not necessarily choose snack products at higher prices. Income groups $>$ Rp20,000,000 might choose snack products not only by price factors, but also consider other factors such as product taste, nutritional content of the product, or halal and food safety certification.

\section{Alternative Strategies of Snack Digital Marketing}

The alternative strategy formulation of this study was based on the $4 \mathrm{C}$ marketing mix. The $4 \mathrm{C}$ marketing mix concept focuses more on the interests of consumers. The following was an alternative explanation of digital marketing strategies for snack SMEs in the City of Bogor.

Increasing Durability of Snack Products

Choosing the right packaging for snacks could help increase product durability. Plastic packaging was the type of snack packaging that was most preferred by producers and consumers. Efforts to made increase the durability of snack food products, one of which is to complement the packaging with the composition of air that has been modified in it, oxygen, carbon dioxide, or inert gas with adequate balance and must also be resistant to mechanical pressure. In addition, air composition in the packaging of snack products can help MSMEs to keep the product from being easily destroyed during the shipping process.

Providing a Variety of Snack Flavors

The development of various types of food with a variety of unique and interesting flavors would certainly be an attraction for consumers. The variety of flavors in every snack product offered could certainly satisfy the 
diverse tastes of consumers. In addition, the variation of taste in a product was expected to reduce the satiety that arises when consuming the same type of product repeatedly. This strategy could prevent consumers from moving to buy competitors' products.

Designing the Appearance of Packaging and Catchy Brands

Consumers' interest in buying snacks could arise by looking at the packaging of snack products. In addition, the brand has an important role for a product. Unique and catchy brands would certainly be easier for consumers to remember. Zulkarnaen and Sutopo (2013) said that MSME could improve their quality product by improving the packaging used.

\section{Inclusion of Product Nutrition Information}

Inclusion of nutritional information on snack food product packaging was one of the means of snack MSMEs to provide information openly related to the product's composition ingredients. This information becomes important for consumers to tell various nutrients contained in the snacks. This effort was done to ensure consumers that the product was safe for consumption.

\section{Affordable Product Pricing}

Determine the selling price of snacks that could be done based on the consumers' purchasing ability. The average consumer was willing to buy snacks at a price range of Rp10,000 - Rp20,000 per 100 grams of product. However, MSMEs could also determine the selling price of products based on the level of income consumers who were their target markets.

\section{Selection of Appropriate Information Media}

The selection of information media used by snack MSMEs in the City of Bogor in conveying information related to their products needs to be adjusted to the media used by consumers in finding snack information. It was known that two types of digital media that were often used by consumers to search for snacks information, which were marketplace and Instagram. MSMEs could also choose the type of information media based on the age of the consumers who were their target markets.

\section{Selection of the Right Promotion Media}

Short video content was very popular with consumers. The combination of audio and visual elements could increase consumer appeal of the content presented. In addition, female consumers were also interested in marketing forms that involve celebrities or influencers, commonly known as endorsements. Both types of promotional media were considered effective by consumers in providing snack food information.

\section{Providing Attractive Promotions for Consumers}

Various efforts have been made by producers to attract consumer interest to buy the products they offer. The form of promotion given to consumers should be adjusted to consumers' preferences. Offers in the form of discounts and free shipping are highly sought after by consumers in buying snacks online.

\section{Showing Consumer Testimonials}

One of the factors that can influence consumers in making snacks purchase decisions online was by looking at product reviews provided by other consumers. Consumers believe that product testimonials from other consumers were honest opinions regarding the condition and quality of the product purchased.

\section{Honestly Display Pictures and Product Descriptions}

Product images and descriptions were the main information needed by consumers when buying snacks online. The limitation of consumers to see the appearance of the product directly makes the images and descriptions displayed by the seller very important. The seller's means to display the product image and product description honestly can certainly increase consumer trust to the seller.

\section{Providing Various Types of Payment Tools}

Ease of payment when buying snacks online was certainly a factor considered by consumers. The availability of various payment media options needs to be considered by snack MSMEs in their products online marketing. Providing electronic payment is one of the alternative payment strategies to make consumers easily buying a snack. 


\section{Managerial Implications}

Changes in consumer's snack consumption patterns that are so fast encourage snack producers to be adapted to current market needs. Snack MSME are supported for adapt their snack products with the needs of consumers. This can be seen from several attributes of food products needed by consumers that are not provided by producers, such as product durability, variations in product taste, and variations in product size.

Various forms of services provided by snack producers have an important role in supporting snack marketing. Snack producers must be able to provide services as desired and needed by consumers. Various forms of services needed by consumers such as providing descriptions and images that match the product, providing attractive promotions, and providing a variety of payment instruments.

Current marketing strategies of Snack MSME do not only focus on the products produced. Sanck MSME must be able to market their products and services according to customer needs. This is an effort to adapt to changes in consumer behavior at the moment.

\section{CONCLUSIONS AND RECOMMENDATIONS}

\section{Conclusions}

Changes in consumer's snack consumption patterns that so fast encourage snack producers to be adapted to current market needs. Snack MSMEs are supported to adapt their snack products with the needs of consumers. This can be seen from several attributes of food products needed by consumers that are not provided by producers, such as product durability, variations in product taste, and variations in product size.

The availability of snack products following customer needs could make these products the first choice for consumers. That makes consumers more likely to repurchase the product. So producers could prevent consumers from buying competitor products.

Various forms of services provided by snack producers have an important role in supporting snack marketing. Snack producers must be able to provide services as desired and needed by consumers. Various forms of services needed by consumers such as providing descriptions and images that match the product, providing attractive promotions, and providing a variety of payment instruments

The availability of good service from producers would increase consumer satisfaction. This will have an impact on the positive impression given by consumers. So they would share the information with other potential customers.

\section{Recommendations}

The study of Digital Marketing Strategies for Snack MSMEs in Bogor currently focuses on improving the performance of digital marketing through evaluations of products marketed, product selling prices, distribution channels, and promotional activities carried out by MSMEs. Future studies can certainly analyze the improvement in performance of snack marketing SMEs digital which focuses on the ability of human resources owned. Basically, the ability of human resources is known to be a driver of the success of a business.

\section{REFERENCES}

Bhayani S, Vachhani NV. 2014. Internet marketing vs traditional marketing: a comparative analysis. FIBB Business Review 3(3): 53-63. https://doi. org/10.1177/2455265820140309.

[BPS] Badan Pusat Statistik. 2017. Perkembangan Data Usaha Mikro, Kecil, Menengah (UMKM) dan Usaha Besar (UB) Tahun 2016 - 2017. Jakarta: BPS.

Dewi AM. 2018. Pengaruh iklan online melalui instagram terhadap keputusan pembelian bagi peningkatan penjualan produk kuliner lokal. EKONIKA 3(1): 1-22.https://doi.org/10.30737/ ekonika.v3i1.78.

Gunartin. 2017. Penguatan UMKM sebagai pilar membangun ekonomi bangsa. Jurnal Pendidikan, Hukum, dan Bisnis 1(5): 59-74.

Kama. 2018. Inilah tren E-Commerce2018 di Indonesia, menurut toko online ini. https://nextren.grid.id/ $\mathrm{read} / 0124363 /$ inilah-tren-e-commerce-2018di-indonesia-menurut-toko-online-ini?page $=2$. [2019 Nov 3].

[KEMENTAN] Kementerian Pertanian. 2018. Statistik Konsumsi Pangan Tahun 2018. Jakarta: Sekretariat Jenderal Kementerian Pertanian.

Khairani Z, Soviyant E, Aznuriyandi. 2018. Efektivitas 
promosi melalui instagram pada umkm sektor makanan dan minuman di kota Pekanbaru. Jurnal Benefita 3(1): 239-247.https://doi.org/10.22216/ jbe.v3i2.2738.

[KOMINFO] Kementerian Komunikasi dan Informatika. 2018. UMKM Go Online. Jakarta: Dirjen Aplikasi Informatika Kementerian Komunikasi dan Informatika.

Kusumawaty Y. 2018. Strategi pemasaran produk makanan ringan khas Riau (keripik nenas dan rengginang ubi kayu). Jurnal Agribisnis 20(2): 124-138. https://doi.org/10.31849/agr. v20i2.2235.

Lisawati P. 2016. Efektivitas iklan pada jejaring sosial sebagai salah satu strategi pemasaran bisnis UKM. J. Ekonomi Bisnis. 21(3): 153-159.

Lodhi S dan Shoaib M. 2017. Impact of e-marketing on consumer behaviour: a case of Karachi, Pakistan. IOSR-JBM. 19(1): 90-101.https://doi. org/10.9790/487X-19010590101.

Maulida S dan Yunani A. 2017. Peluang dan tantangan pengembangan usaha mikro kecil menengah (UMKM) dari berbagai aspek ekonomi. J. Ilmiah Manajemen dan Bisnis 2(1): 181-197.

Mokhtar NF, Hasan ZRA, Halim ASA. 2017. The social media and marketing strategies: how it impacts the small and medium sized enterprises business performance. Australian Journal of Business and Management Research 3(4): 184-190.
Priambada S. 2017. Potensi media sosial bagi usaha kecil dan menengah (UKM) di Malang Raya. SESINDO. 239-244.

Setiawan TF, Suharjo B, Syamsun M. 2018. Strategi pemasaran online UMKM makanan (studi kasus di kecamatan cibinong). Jurnal Manajemen IKM. 13(2):116-126. https://doi.org/10.29244/ mikm.13.2.116-126.

Srirejeki K. 2016. Analisis manfaat media sosial dalam pemberdayaan usaha mikro kecil menengah (umkm). Jurnal Masyarakat Telematika dan Informasi 7(1): 57-68

Srinivisan R, Bajaj R, Bhanot S. 2016. Impact of social media marketing strategies used by micro, small, and medium enterprises (MSMEs) on customer acquisition and retention. Journal Business and Management 18(1): 91-101.

Stockdale R, Ahmed A, Scheepers H. 2012. Identifying business value from the use of social media: an sme perspective. PACIS Proceeding. Association for Information System Electronic Library.

Yildiz SM. 2011. An importance-performance analysis of fitness centre service quality: empirical result from fitness centre in Turkey. African Journal of Business Management 14(3): 104-111.

Zulkarnaen HO, Sutopo. 2013. Analisis strategi pemasaran pada usaha kecil menengah (UKM) makanan ringan (studi penelitian UKM snack barokah di Solo). Journal Management 2(3): $1-10$. 